Prepar at i on and El ect rochemical Properti es of Cat hode Nateri al s for Li thi um I on Bat tery by Aer osol Process

\begin{tabular}{|l|l|}
\hline 著者 & $\begin{array}{l}\text { OG HARA Takashi, KODERA Takayuki, MOUJIN } \\
\text { Keni chi , MOTOH RA Shi ger u }\end{array}$ \\
\hline $\begin{array}{l}\text { j our nal or } \\
\text { publ i cat i on ti tl e }\end{array}$ & Nat er i al s Sci ence and Engi neer i ng B \\
\hline vol ume & 161 \\
\hline page $r$ ange & $109-114$ \\
\hline year & $2009-06$ \\
\hline URL & ht t p: //hdl . handl e. net /10098/2321 \\
\hline
\end{tabular}




\title{
Preparation and Electrochemical Properties of Cathode Materials for Lithium Ion Battery by Aerosol
}

\section{Process}

\author{
Takashi Ogihara, Takayuki Kodera, Kenichi Myoujin and Shigeru Motohira \\ Department of Fiber Amenity Engineering, University of Fukui \\ 3-9-1 Bunkyo, Fukui-shi, Fukui, 910-8507 JAPAN \\ ogihara@matse.fukui-u.ac.jp
}

\begin{abstract}
Lithium transition metal oxide powders such as $\mathrm{LiMn}_{2} \mathrm{O}_{4}, \mathrm{LiNi}_{0.5} \mathrm{Mn}_{1.5} \mathrm{O}_{4}, \mathrm{LiCo}_{1 / 3} \mathrm{Ni}_{1 / 3} \mathrm{Mn}_{1 / 3} \mathrm{O}_{2}$ and $\mathrm{LiFePO}_{4}$ were prepared by spray pyrolysis. The particle characteristics of them were determined by SEM, XRD, BET and AAS. Lithium transition metal oxide powders had spherical morphology of 1- $2 \mu \mathrm{m}$ with narrow size distribution and homogeneous chemical composition. The electrochemical properties of cathode were also estimated by rechargeable capacity, cycle performance, thermal stability and high rate charging. The cathodes obtained by spray pyrolysis exhibited higher rechargeable capacity and good cycle stability. Mass production of lithium transition metal oxide powders was carried out by using internal combustion type of spray pyrolysis. The electrochemical properties of cathode obtained by internal combustion type spray pyrolysis were comparable with these obtained by spray pyrolysis.
\end{abstract}

\section{Keywords: Lithium ion battery, Oxide, Aerosol, Spray pyrolysis}

\section{Introduction}

Lithium ion batteries have been extensively used as energy storage devices for portable electronics. Recently, these are well noted as the power sources for the vehicles such as EV and $\mathrm{HEV}$ [1]. Both layered type $\mathrm{LiCoO}_{2}$ and spinel type $\mathrm{LiMn}_{2} \mathrm{O}_{4}$ is the most important cathode materials because of their high operating voltage at $4 \mathrm{~V}$ $[2,3] . \mathrm{LiCoO}_{2}$ have been mostly used as cathode material of commercial lithium ion batteries. However, $\mathrm{LiCoO}_{2}$ has a problem related to capacity fading due to the instability in rechargeable cycles. Cobalt is also expensive and its resource is not sufficient. Therefore, $\mathrm{LiCoO}_{2}$ cathode material is not suitable as a lithium ion battery for EV and $\mathrm{HEV}$. $\mathrm{LiMn}_{2} \mathrm{O}_{4}$ is regarded as a promising cathode material for large lithium ion batteries due to their 
advantages such as low cost, abundance, non-toxicity and thermally stable [4]. It was also known that Ni-substitute lithium manganese oxide spinel $\left(\mathrm{LiNi}_{0.5} \mathrm{Mn}_{1.5} \mathrm{O}_{4}\right)$ was exhibited rechargeable behavior at about $5 \mathrm{~V}$ $[5,6] . \mathrm{LiNi}_{0.5} \mathrm{Mn}_{1.5} \mathrm{O}_{4}$ has been considerably noticed as a cathode material with high power density. Park et.al., reported [7] that $\mathrm{Li} \mathrm{Ni}_{0.5} \mathrm{Mn}_{1.5} \mathrm{O}_{4}$ cathode obtained by spray pyrolysis exhibited excellent rechargeable capacity and stable cycle perfomance. The layered type $\mathrm{LiCo}_{1 / 3} \mathrm{Ni}_{1 / 3} \mathrm{Mn}_{1 / 3} \mathrm{O}_{2}$ was found to exhibit superior high potential cathode properties. This shows rechargeable capacity with more $150 \mathrm{mAh} / \mathrm{g}$ at higher charge rate and milder thermal stability [8]. Park et.al., also reported [9] that $\mathrm{LiCo}_{1 / 3} \mathrm{Ni}_{1 / 3} \mathrm{Mn}_{1 / 3} \mathrm{O}_{2}$ obtained by spray pyrolysis exhibited excellent rechargeable properties as well as $\mathrm{Li} \mathrm{Ni}_{0.5} \mathrm{Mn}_{1.5} \mathrm{O}_{4}$ cathode. Recently, olivine-type $\mathrm{LiFePO}_{4}$ is noted as cathode material for lithium ion batteries because of low-cost, environmentally friendly, high thermally stability and electrochemical performance. $\mathrm{LiFePO}_{4}$ shows a very flat voltage curve with a plateau around $3.5 \mathrm{~V}$ and rechargeable capacity of $170 \mathrm{mAh} / \mathrm{g}$ [10-12]. In order to use as cathode, $\mathrm{C} / \mathrm{LiFePO}_{4}$ composites powders were often prepared by coating conducting materials such as carbon because they had poor electric conductivity [13]. The advantage of spray pyrolysis is that it is possible to directly contain the carbon during the powder preparation using organic compound [14].

For above cathode materials, the spray pyrolysis is an effective process for the rapid synthesis of homogeneous cathode materials. We have been tried to synthesize various type oxide materials such as $\mathrm{LiCoO}_{2}, \mathrm{LiNiO}_{2}$ and $\mathrm{LIMn}_{2} \mathrm{O}_{4}$ for lithium ion battery by spray pyrolysis [15-17]. It was reported that the rechargeable capacity and cycle performance of lithium ion battery were improved by using the cathode materials for lithium ion battery derived from spray pyrolysis. In this paper, the particle characterization and electrochemical properties of lithium transition metal oxide powders produced by spray pyrolysis were described. Furthermore, the mass production apparatus in which the aerosols were efficiently pyrolyzed in flame generated by gas burner (internal combustion type spray pyrolysis) was developed in order to solve the problem of large-scale production of cathode materials. The electrochemical properties of them were also described.

\section{Experimental procedures}

\subsection{Powder preparation of spray pyrolysis}


Metal nitrates were used as starting materials. $\mathrm{H}_{3} \mathrm{PO}_{4}$ was also used as raw materials for $\mathrm{LiFePO}_{4}$. They were dissolved in an appropriate atomic molar ratio to prepare the starting solution. Furthermore, various types of organic acid were added to aqueous solutions up to $60 \mathrm{wt} \%$ in the preparation of starting solution of $\mathrm{LiFePO}_{4}$. The starting solution prepared was atomized to generate the aerosol by using an ultrasonic vibrator with $2.4 \mathrm{MHz}$. The spray pyrolysis apparatus is shown in elsewhere [18]. The aerosol of starting solution was introduced into quartz tube $(38 \mathrm{~mm} \phi \times 2000 \mathrm{~mm})$ in the electrical furnace with air carrier gas $\left(6 \mathrm{dm}^{3} / \mathrm{min}\right)$. The aerosol was drying at $400{ }^{\circ} \mathrm{C}$ and then pyrolyzed at $900{ }^{\circ} \mathrm{C}$. As-prepared particles were continuously collected using the cyclone.

\subsection{Mass production by internal combustion types spray pyrolysis}

Figure 1 shows the picture and schematic diagram of internal combustion types spray pyrolysis apparatus [19]. This apparatus $(0.4 \mathrm{~m} \phi \times 6 \mathrm{~m} \times 8 \mathrm{~m})$ consisted of two-fluid nozzle atomizer (a), combustion furnace with gas burner using city gas (b) and powder collection box using bag filter (c). The aerosol of aqueous nitrate solutions was generated by two-fluid nozzle atomizer with flow rate of $10 \mathrm{dm}^{3} / \mathrm{h}$. The aerosol was continuously sprayed from the upper part of combustion furnace to the downward and then pyrolyzed when the aerosol passed through the flame set at $500{ }^{\circ} \mathrm{C}$. This apparatus have the powder production potential of $1 \mathrm{~kg} / \mathrm{hr}$. It is possible to produce lithium transition metal oxide powders of $2000 \mathrm{~kg} / \mathrm{month}$ by this apparatus.

\subsection{Powder characterization and electrochemical properties}

Crystal phase of lithium transition metal oxide powders was identified by powder X-ray diffraction (XRD, Shimadzu, XRD-6100) using $\mathrm{CuK} \alpha$ radiation. The average particle size and morphology of them were determined by scanning electron microscope (SEM, Hitachi, S-2300). The average particle size was determined by randomly sampling 200 particles from SEM photographs. Specific surface area of lithium transition metal oxide powders was measured by BET method using $\mathrm{N}_{2}$ adsorption (SSA, Shimadzu, Tristar-3000). The chemical composition of them was determined by atomic adsorption spectrum analysis (AAS, Shimadzu, AAS-6800).

The heat treatment was carried out at $750{ }^{\circ} \mathrm{C}$ for $2 \mathrm{hr}$ under the air condition to obtain the cathode materials with well crystallization. $\mathrm{LiFePO}_{4}$ was also heated at $600{ }^{\circ} \mathrm{C}$ for $2 \mathrm{hr}$ under the argon/hydrogen $(5 \%)$ atmosphere 
to prevent the volatile of carbon. Cathode was prepared using $80 \mathrm{wt} \%$ of cathode material powders, $10 \mathrm{wt} \%$ of acetylene black and $10 \mathrm{wt} \%$ of fluorine resin. They were mixed to obtain slurry and then coated on aluminum sheet using doctor blade. Li sheet was used as an anode. The polypropylene sheet was used as a separator. 1 mol• $\mathrm{dm}^{-3} \mathrm{LiPF}_{6}$ in ethylene carbonate / 1,2-dimethoxyethane (EC : DME = 1:1) was used as the electrolyte. 2032 coin type of lithium ion cell was built up in globe box under an argon atmosphere. The change of voltage during charge/discharge was measured with a battery tester (Hosen, BTS2004) at between 3.0 V and 4.3 V. The current density ranged from $0.3(1 \mathrm{C})$ to $6(20 \mathrm{C}) \mathrm{mA} / \mathrm{cm}^{2} .1 \mathrm{C}$ means that the rechargeable process is done for $1 \mathrm{hr}$.

\section{Results and discussion}

\subsection{Powder characterization of lithium transition metal oxide}

Figure 2 shows typical SEM photographs of lithium transition metal oxide powders prepared by spray pyrolysis. SEM photograph revealed that these powders had the spherical morphology with non-aggregation regardless of the types of starting materials. The average particle size of them determined by SEM photograph was about $1-2 \mu \mathrm{m}$. The geometrical standard deviation of average particle size ranged from 1.2 to 1.5. These powders had relatively narrow size distribution. Table 1 shows SSA of them measured by BET method. SSA of them ranged from 1 to $4 \mathrm{~m}^{2} / \mathrm{g}$.

XRD patterns of lithium transition metal oxide powders are shown in Fig.3. The diffraction peaks of $\mathrm{LiAl}_{0.05} \mathrm{Mn}_{1.95} \mathrm{O}_{4}$ and $\mathrm{LiNi}_{0.5} \mathrm{Mn}_{1.5} \mathrm{O}_{4}$ were good agreement with spinel structure (space group $\mathrm{Fd} 3 \mathrm{~m}$ ). The diffraction lines of impurities (e.g. $\mathrm{Al}_{2} \mathrm{O}_{3}, \mathrm{Mn}_{2} \mathrm{O}_{3}, \mathrm{Li}_{2} \mathrm{CO}_{3}$ ) were not identified. Aluminum was uniformly doped and nickel was substituted in $\mathrm{Mn}$ site. The diffraction peaks of $\mathrm{LiCo}_{1 / 3} \mathrm{Ni}_{1 / 3} \mathrm{Mn}_{1 / 3} \mathrm{O}_{2}$ were also identified to layered structure (space group $\mathrm{R} 3 \mathrm{~m}$ ). Furthermore the diffraction peaks of $\mathrm{LiFePO}_{4}$ were identified to olivine structure (space group Pnma). Table 2 shows the chemical composition of lithium transition metal oxide powders determined by AAS. The chemical composition of them was good agreement with starting solution composition. This suggested that the content of each metal was uniformly maintained in each aerosol.

\subsection{Electrochemical properties of cathode material}

The electrochemical measurement of cathode which was produced by lithium transition metal oxide powders 
derived from spray pyrolysis was examined. Figure 4 shows the charge and discharge curves of cathode at rate of $1 \mathrm{C}$ (Current density : $0.3 \mathrm{~mA} / \mathrm{cm}^{2}$ ). The discharge capacity of $\mathrm{LiAl}_{0.05} \mathrm{Mn}_{1.95} \mathrm{O}_{4}$ and $\mathrm{LiNi}_{0.5} \mathrm{Mn}_{1.5} \mathrm{O}_{4}$ was 125 and $145 \mathrm{mAh} / \mathrm{g}$, respectively. Al doping led to the disappearance of typical voltage jump at $4 \mathrm{~V}$ and then the $\mathrm{S}$ curve with average operating voltage of 3.6 was observed. On the other hand, the average operation voltage increased up to $4.7 \mathrm{~V}$ by substituting $\mathrm{Ni}$ to $\mathrm{LiMn}_{2} \mathrm{O}_{4}$. This suggested that the application as high power sources such as electric tool was expected. The discharge capacity of $\mathrm{LiCo}_{1 / 3} \mathrm{Ni}_{1 / 3} \mathrm{Mn}_{1 / 33} \mathrm{O}_{2}$ and $\mathrm{LiFePO}_{4}$ was 180 and $150 \mathrm{mAh} / \mathrm{g}$, respectively and had higher capacity than $\mathrm{LiMn}_{2} \mathrm{O}_{4}$. The discharge capacity of $\mathrm{LiFePO}_{4}$ without carbon was 40 $\mathrm{mAh} / \mathrm{g}$. The rechargeable capacity of $\mathrm{LiFePO}_{4}$ was considerably improved by the addition of carbon. It was shown that the cathode had the excellent discharge capacity and was expected to apply as high energy sources such as HEV. The long plateau was observed at about $3.5 \mathrm{~V}$ in the discharge curve of $\mathrm{LiFePO}_{4}$.

Figure 5 shows the relation between cycle number and discharge capacity of $\mathrm{LiAl}_{0.05} \mathrm{Mn}_{1.95} \mathrm{O}_{4}$ cathode at rate from $1 \mathrm{C}$ to $15 \mathrm{C}$. The rechargeable test was carried out up to 1000 times. It was clear that the excellent cycle stability was shown. The discharge capacity was reduced to $80 \%$ of initial discharge capacity after about 1000 cycle number at rate of $1 \mathrm{C}$. The discharge capacity of $\mathrm{LiAl}_{0.05} \mathrm{Mn}_{1.95} \mathrm{O}_{4}$ cathode decreased with increasing charging rate. The discharge capacity reduced to about $70 \mathrm{mAh} / \mathrm{g}$ at a rate of $15 \mathrm{C}$. The discharge capacity was maintained more $90 \%$ of initial discharge capacity at rate of more $5 \mathrm{C}$. This suggested that the addition of $\mathrm{Al}$ led to the increase of Mn valence.

Figure 6 shows the relation between cycle number and discharge capacity of $\mathrm{LiNi}_{0.5} \mathrm{Mn}_{1.5} \mathrm{O}_{4}$, $\mathrm{LiCo}_{1 / 3} \mathrm{Ni}_{1 / 3} \mathrm{Mn}_{1 / r 3} \mathrm{O}_{2}$ and $\mathrm{LiFePO}_{4}$ cathode at rate from $1 \mathrm{C}$ to $15 \mathrm{C}$. $\mathrm{LiNi}_{0.5} \mathrm{Mn}_{1.5} \mathrm{O}_{4}$ maintained $92 \%$ of initial discharge capacity after about 500 cycle number at rate of $1 \mathrm{C}$. The discharge capacity reduced to about $70 \mathrm{mAh} / \mathrm{g}$ at a rate of $15 \mathrm{C}$, but maintained $89 \%$ of initial discharge capacity. $\mathrm{LiCo}_{1 / 3} \mathrm{Ni}_{1 / 3} \mathrm{Mn}_{1 / 33} \mathrm{O}_{2}$ maintained $80 \%$ of initial discharge capacity after about 500 cycle number at rate of $1 \mathrm{C}$. The discharge capacity reduced to about 90 $\mathrm{mAh} / \mathrm{g}$ at a rate of $15 \mathrm{C} . \mathrm{LiFePO}_{4}$ maintained $84 \%$ of initial discharge capacity after about 500 cycle number at rate of $1 \mathrm{C}$. The discharge capacity reduced to about $70 \mathrm{mAh} / \mathrm{g}$ at a rate of $15 \mathrm{C}$, but maintained $94 \%$ of initial discharge capacity. 
Figure 7 shows the relation between cycle number and discharge capacity of cathode at $50^{\circ} \mathrm{C}$ and $60{ }^{\circ} \mathrm{C}$. The rechargeable test carried out up to 300 cycles at rate of $1 \mathrm{C}$. The cycle stability of $\mathrm{LiAl}_{0.05} \mathrm{Mn}_{1.95} \mathrm{O}_{4}$ and $\mathrm{LiNi}_{0.5} \mathrm{Mn}_{1.5} \mathrm{O}_{4}$ cathodes at $50{ }^{\circ} \mathrm{C}$ and $60{ }^{\circ} \mathrm{C}$ was maintained as well as the room temperature. The discharge capacity of $\mathrm{LiCo}_{1 / 3} \mathrm{Ni}_{1 / 3} \mathrm{Mn}_{1 / 3} \mathrm{O}_{2}$ and $\mathrm{LiFePO}_{4}$ cathodes gradually decreased with increasing cycle number at $60{ }^{\circ} \mathrm{C}$. The discharge capacity of $\mathrm{LiCo}_{1 / 3} \mathrm{Ni}_{1 / 3} \mathrm{Mn}_{1 / 3} \mathrm{O}_{2}$ and $\mathrm{LiFePO}_{4}$ cathodes was $74 \%$ and $77 \%$ of discharge capacity, respectively.

\subsection{Mass production of cathode materials by internal combustion type spray pyrolysis}

It is difficult for spray pyrolysis to homogeneously pyrolyze a large quantity of aerosol at short time in the electrical furnace that the scale-up was done. In the spray pyrolysis, the difference of pyrolysis temperature inside and outside of the electrical furnace increases with increasing the dimension of electrical furnace. So far, we have been developed the internal combustion type spray pyrolysis apparatus by using gas burner to produce homogeneous cathode materials at large-scale furnace. As a result, it would be possible to overcome the problem of mass production by spray pyrolysis. Figure 8 shows SEM photograph and particle size distribution of $\mathrm{LiAl}_{0.05} \mathrm{Mn}_{1.95} \mathrm{O}_{4}$ powders produced by this apparatus. They had the spherical morphology and consisted of primary particles. They are seen like the porous particle from SEM photograph. The average particle size of $\mathrm{LiAl}_{0.05} \mathrm{Mn}_{1.95} \mathrm{O}_{4}$ powders was $2.7 \mu \mathrm{m}$ and had broad size distribution because of use of two-fluid nozzle with 5 $\mu \mathrm{m}$ of diameter. The geometrical standard deviation of average particle size was 1.5. XRD analysis showed that the crystal structure was spinel type structure with space group of Fd3m. SSA of them was $10 \mathrm{~m}^{2} / \mathrm{g}$. The chemical composition analysis showed that the molar ratio of Li : Al: Mn was $0.99: 0.051: 1.95$.

Figure 9 shows the rechargeable properties and cycle performance of $\mathrm{LiAl}_{0.05} \mathrm{Mn}_{1.95} \mathrm{O}_{4}$ cathode at rate from 0.1 C to $10 \mathrm{C}$. The rechargeable capacity of it decreased from $125 \mathrm{mAh} / \mathrm{g}$ to $90 \mathrm{mAh} / \mathrm{g}$, when the charging rate increased from $0.1 \mathrm{C}$ to $10 \mathrm{C}$. The discharge capacity at each rate maintained $90 \%$ of initial discharge capacity after 300 cycles. $\mathrm{LiAl}_{0.05} \mathrm{Mn}_{1.95} \mathrm{O}_{4}$ cathode obtained by internal combustion type spray pyrolysis exhibited the stable cycle performance.

\section{Conclusion}


Spray pyrolysis demonstrated that lithium transition metal oxide powders had spherical and porous particles which have a diameter of about $1 \mu \mathrm{m}$ with narrow size distribution. As-prepared powders have high crystallinity and uniform chemical composition. The electrochemical measurement exhibited that the cathode materials had the higher rechargeable capacity and stable cycle performance. The rechargeable capacity decreased with increasing the charging rate, but the stability of cycle performance was maintained. The stability of cycle performance was also maintained at elevated temperature. It was found that the aerosol process was effective for the preparation of cathode materials. The electrochemical properties of $\mathrm{LiAl}_{0.05} \mathrm{Mn}_{1.95} \mathrm{O}_{4}$ cathode materials obtained by internal combustion type spray pyrolysis were comparable with those obtained by spray pyrolysis.

\section{Acknowledgement}

This work was supported by Development of an Electric Energy Storage System for Grid-connection with New Energy Resources in New Energy and Industrial Technology Development Organization.

\section{References}

[1] E. Karden, S. Ploumen, B. Fricke, T. Miller, K. Snyder, J. Power Sources 168 (2007) 2-11.

[2] K. Mizushima, P.C. Jones, P.J. Wiseman, J.B. Goodenough, Mat. Res. Bull. 15 (1980) 783-789.

[3] D. Guyomard, J.M. Trascon, Solid State Ionics 69 (1994) 222-237.

[4] Z. Pegeng, F. Huiqing, F. Yunfei, L. Zhuo, D. Yongli, Rare Metals 25 (2006) 100-104.

[5] B. Markovsky, Y. Talyossef, G. Salitra, D. Aurbach, H.J. Kim, S. Choi, Electrochem.Commun. 6 (2004) $821-826$.

[6] Y. Idemoto, H. Sekine, K. Ui, N. Koura, Electrochemistry 70 (2004) 564-568.

[7] S.H. Park, Y.K. Sun, Electrochimica Acta 50 (2004) 431-434.

[8] N. Yabuuchi, T. Ohzuku, J. Power Sources 171 (2003) 119-121.

[9] S.H. Park, C.S.Yoon, S.G. Kang, H.S. Kim, S.I. Moon, Y.K. Sun, Electrochimica Acta 49 (2004) 557-563.

[10] A.K.Padhi, K.S.Nanjundaswamy, J.B.Goodenough, J. Electrochem. Soc. 144 (1997) 1188-1194.

[11] A. Yamada, S.C. Chung, K. Hinokuma, J. Electrochem. Soc. 148 (2001) A224-A229.

[12] S.L.Bewlay, K.Konstantinov, G.X.Wang, S.X.Dou, H.K.Liu, Mater. Lett. 58 (2004) 1788-1791. 
[13] J.D. Wilcox, M.M. Doeff, M.Marcinek, R.Kostecki, J. Electrochem. Soc. 154 (2007) A389-A395.

[14] M.R. Yang, T.H. Teng, S.H. Wu, J. Power Sources 159 (2006) 307-311.

[15] T.Ogihara, T.Yanagawa, N.Ogata, K.Yoshida, Y.Mizuno, S.Yonezawa, T.Takashima, N.Nagata, K.Ogawa, Denki Kagaku, 61 (1993) 1339-1341.

[16] T.Ogihara, N.Ogata, S.Yonezawa, M.Takashima, N.Mizutani, Denki Kagaku 66 (1998) 1202-1205.

[17]T.Ogihara, N.Ogata, K.Katayama, Y.Azuma, Electrochemistry 68 (2000) 162-166.

[18]T.Ogihara, T.Ookura, T.Yanagawa, N.Ogata, K.Yoshida, J. Mater. Chem. (1991) 789-794 (1991).

[19] K.Myojin, T.Ogihara, N.Ogata, N.Aoyagi, H.Aikiyo, T.Ookawa, S.Omura, M.Yanagimoto, M.Uede, T.Oohara, Adv. Powder Technol., 15 (2004) 397-403. 
Table 1 and 2

Table 1 SSA of lithium transition metal oxide powders prepared by spray pyrolysis

\begin{tabular}{|l|c|}
\hline \multicolumn{1}{|c|}{ Sample } & $\mathrm{SSA}\left(\mathrm{m}^{2} / \mathrm{g}\right)$ \\
\hline $\mathrm{LiAl}_{0.05} \mathrm{Mn}_{1.95} \mathrm{O}_{4}$ & 2 \\
$\mathrm{LiNi}_{0.5} \mathrm{Mn}_{1.5} \mathrm{O}_{4}$ & 1.6 \\
$\mathrm{LiCo}_{1 / 3} \mathrm{Ni}_{1 / 3} \mathrm{Mn}_{1 / 3} \mathrm{O}_{2}$ & 1 \\
$\mathrm{LiFePO}_{4}$ & 4 \\
\hline
\end{tabular}

Table 2 Chemical composition of lithium transition metal oxide powders prepared by spray pyrolysis

\begin{tabular}{|l|ccccccc|}
\hline & \multicolumn{7}{|c|}{ Atomic concentration (moler ratio) } \\
\cline { 2 - 8 } & $\mathrm{Li}$ & $\mathrm{Al}$ & $\mathrm{Mn}$ & $\mathrm{Co}$ & $\mathrm{Ni}$ & $\mathrm{Fe}$ & $\mathrm{P}$ \\
\hline $\mathrm{LiAl}_{0.05} \mathrm{Mn}_{1.95} \mathrm{O}_{4}$ & 1 & 0.05 & 1.95 & & & & \\
$\mathrm{LiNi}_{0.5} \mathrm{Mn}_{1.5} \mathrm{O}_{4}$ & 1 & & 1.5 & & 0.5 & & \\
$\mathrm{LiCo}_{1 / 3} \mathrm{Ni}_{1 / 3} \mathrm{Mn}_{1 / 3} \mathrm{O}_{2}$ & 1 & & 0.34 & 0.33 & 0.33 & & \\
$\mathrm{LiFePO}_{4}$ & 1 & & & & & 1 & 1 \\
\hline
\end{tabular}


Figure 1
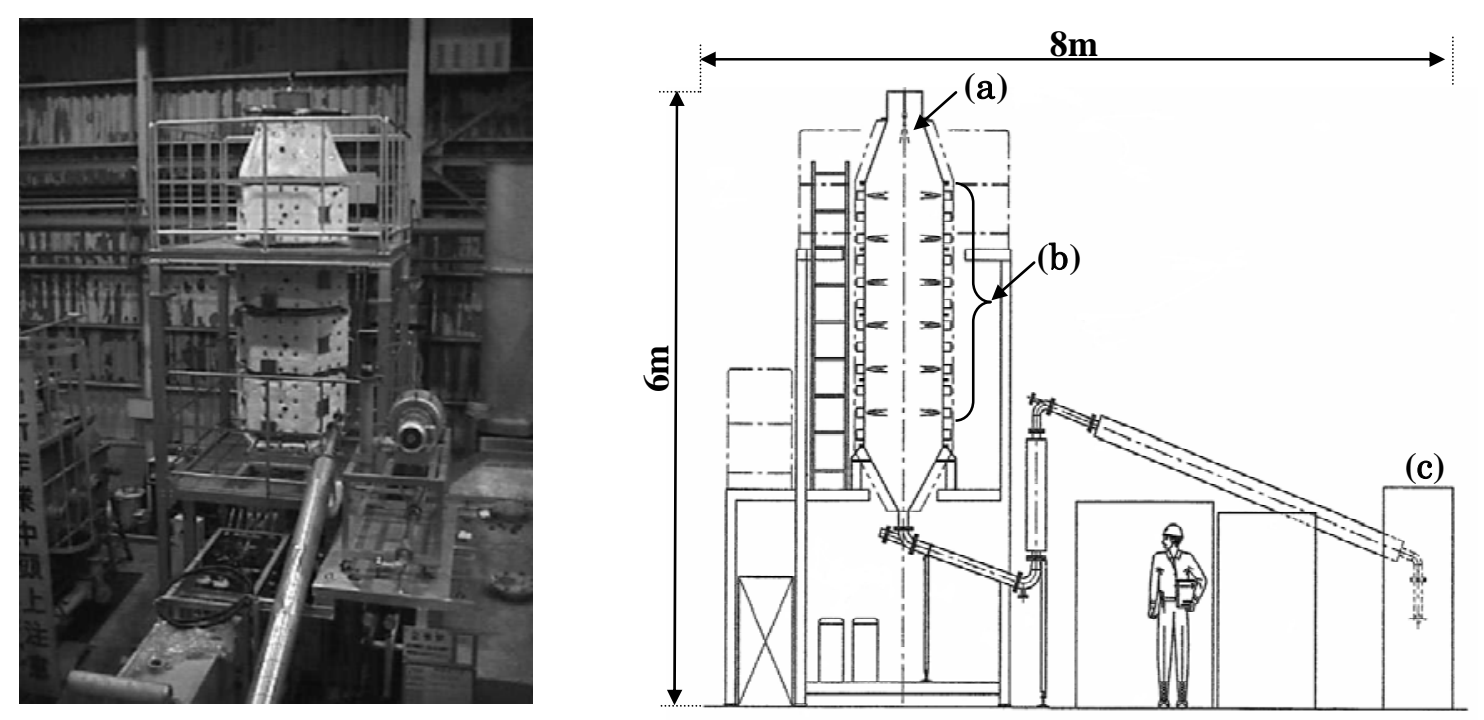

Fig.1 Picture and schematic diagram of internal combustion types spray pyrolysis apparatus, (a) two-fluid nozzle atomizer, (b) combustion furnace, (c) powder collection box 

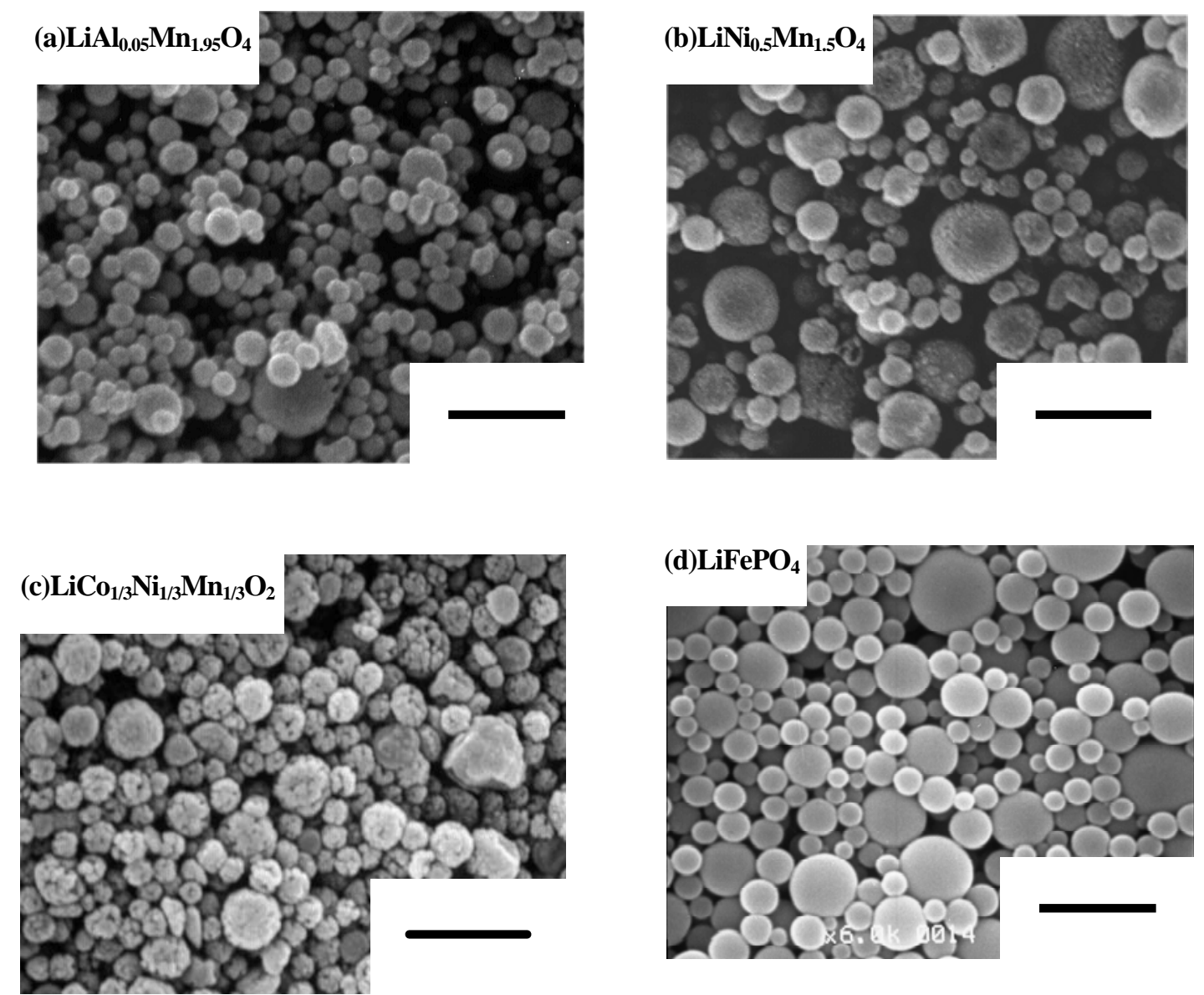

Fig.2 SEM photographs of lithium transition metal oxide powders prepared by spray pyrolysis (bar $=5 \mu \mathrm{m})$. 
Figure 3
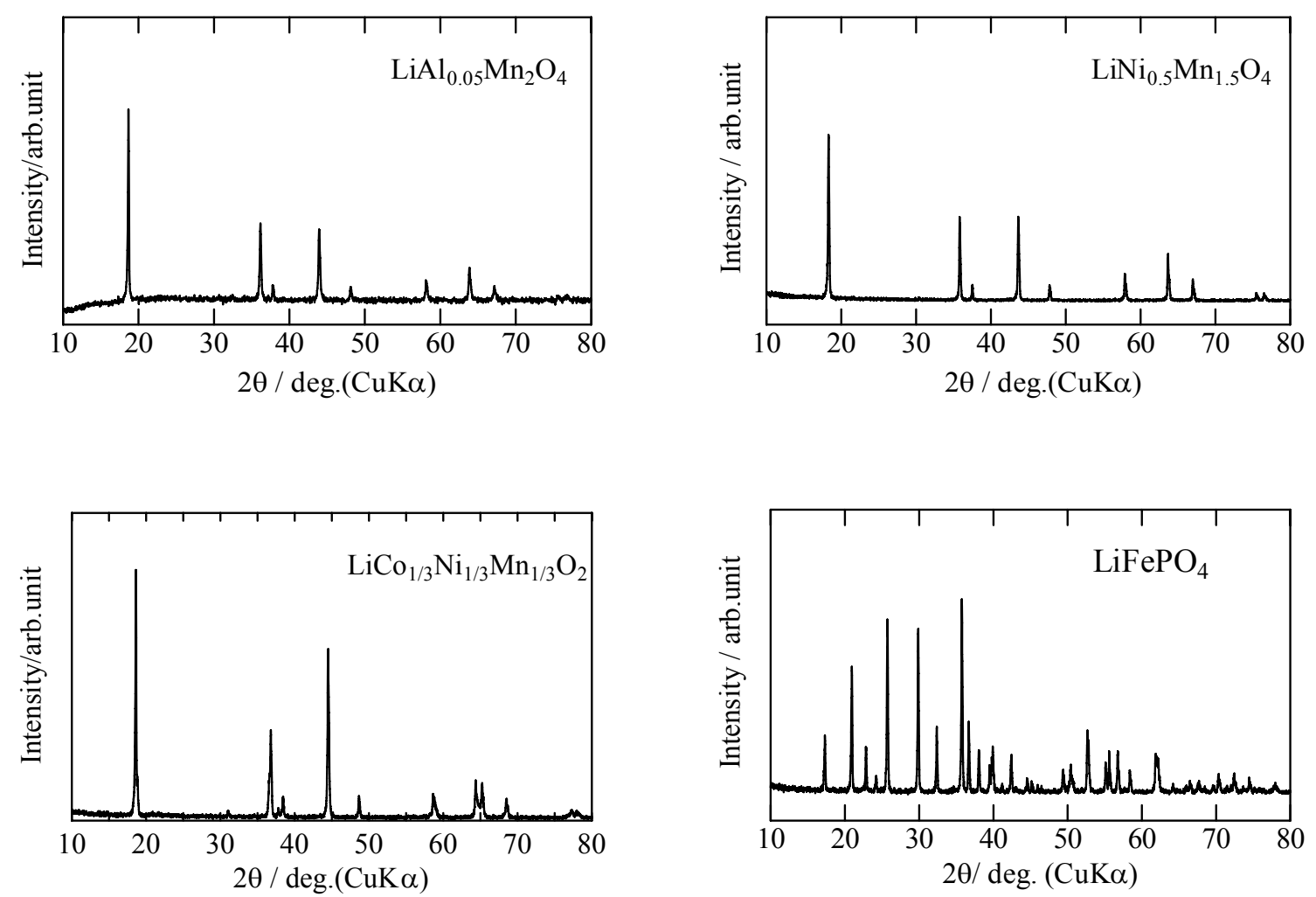

Fig. 3 XRD patterns of lithium transition metal oxide powders prepared by spray pyrolysis 
Figure 4
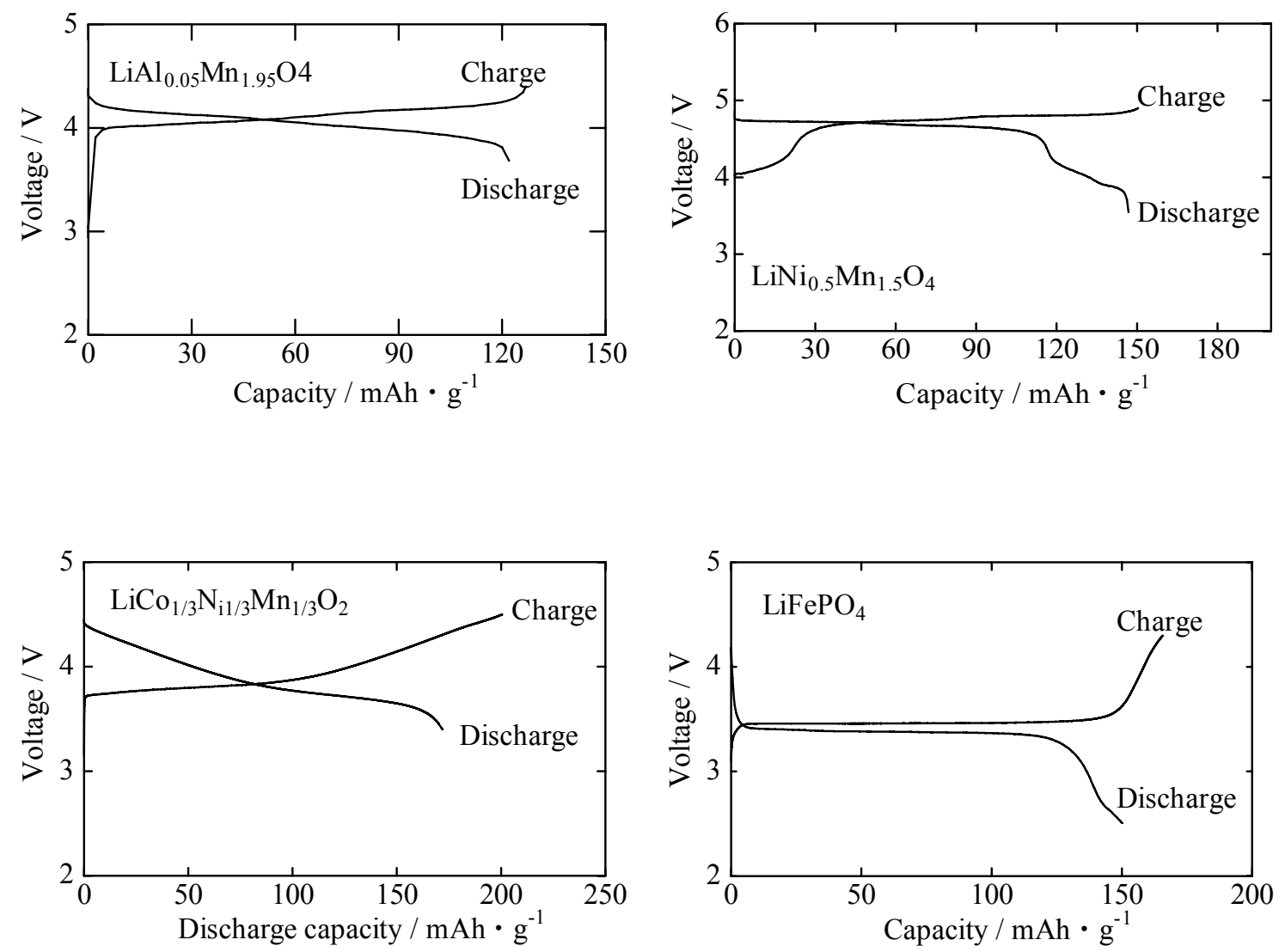

Fig.4 Charge and discharge curves of cathodes at rate of $1 \mathrm{C}$ 
Figure 5

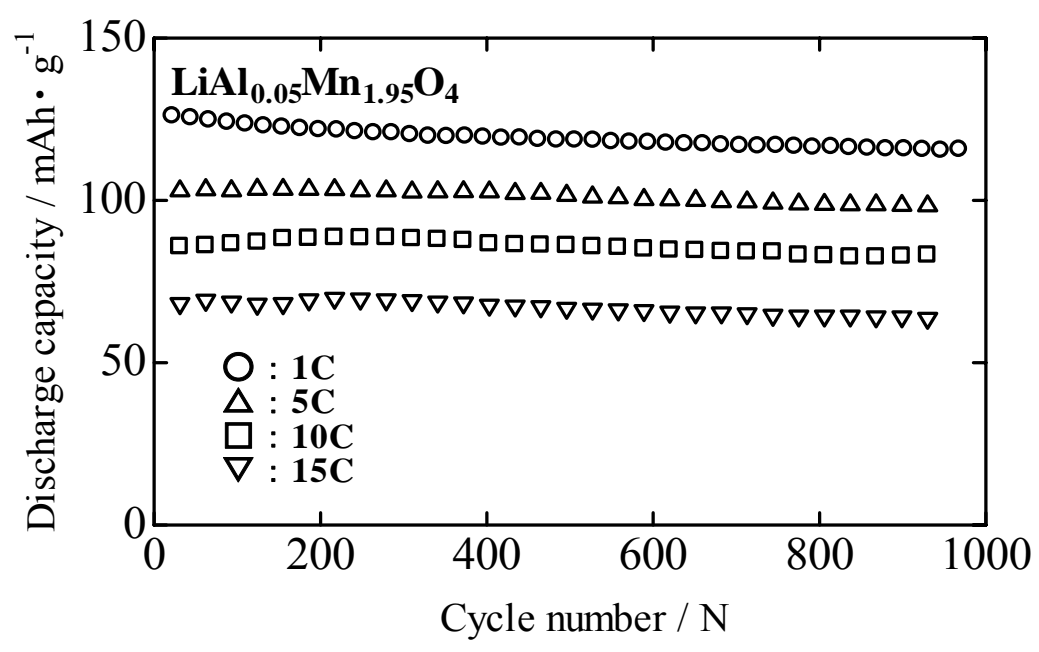

Fig.5 Relation between cycle number and discharge capacity of $\mathrm{LiAl}_{0.05} \mathrm{Mn}_{1.95} \mathrm{O}_{4}$ cathode at rate from $1 \mathrm{C}$ to $15 \mathrm{C}$. 

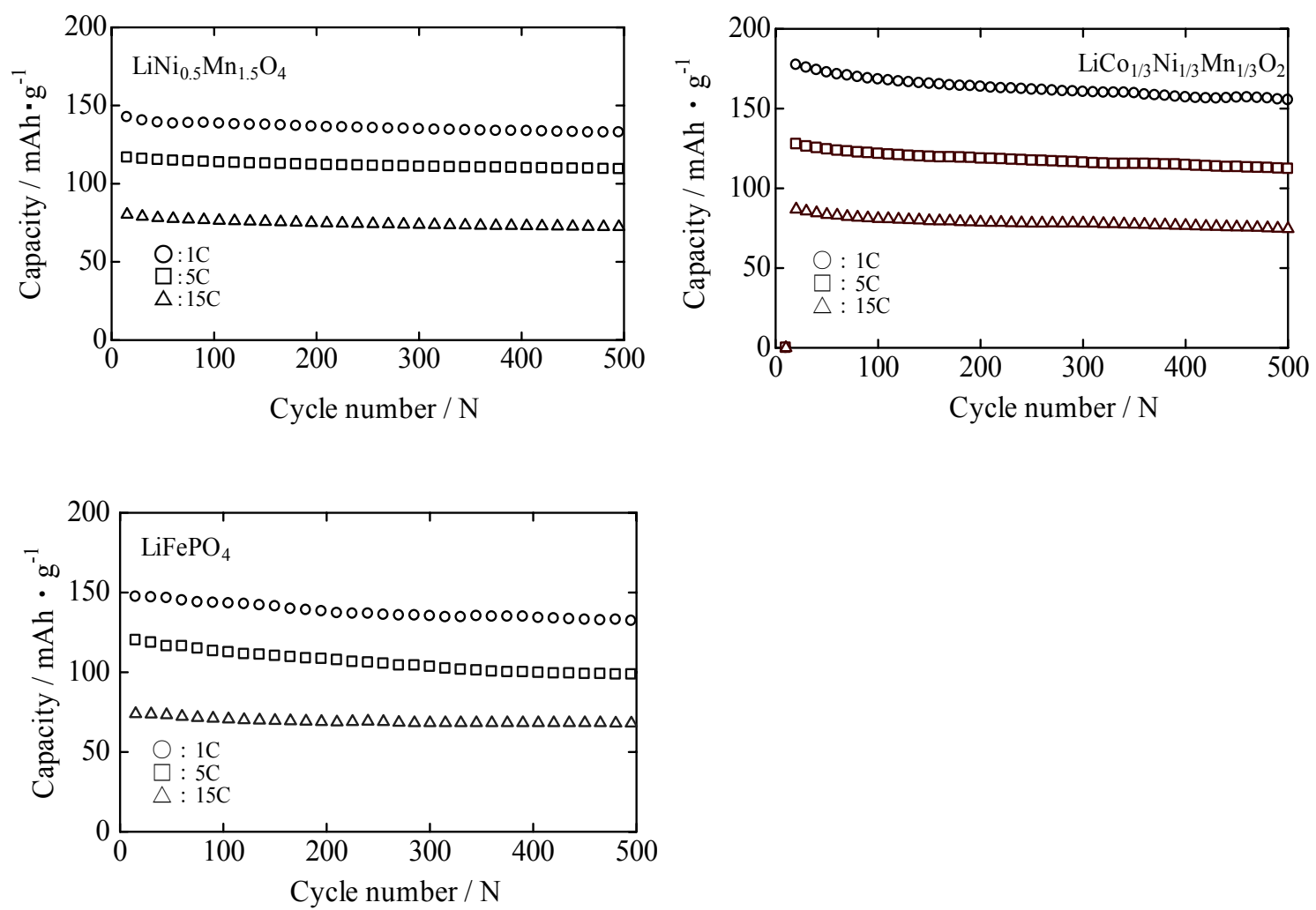

Fig.6 Relation between cycle number and discharge capacity of cathode at rate from $1 \mathrm{C}$ to $15 \mathrm{C}$. 
Figure 7
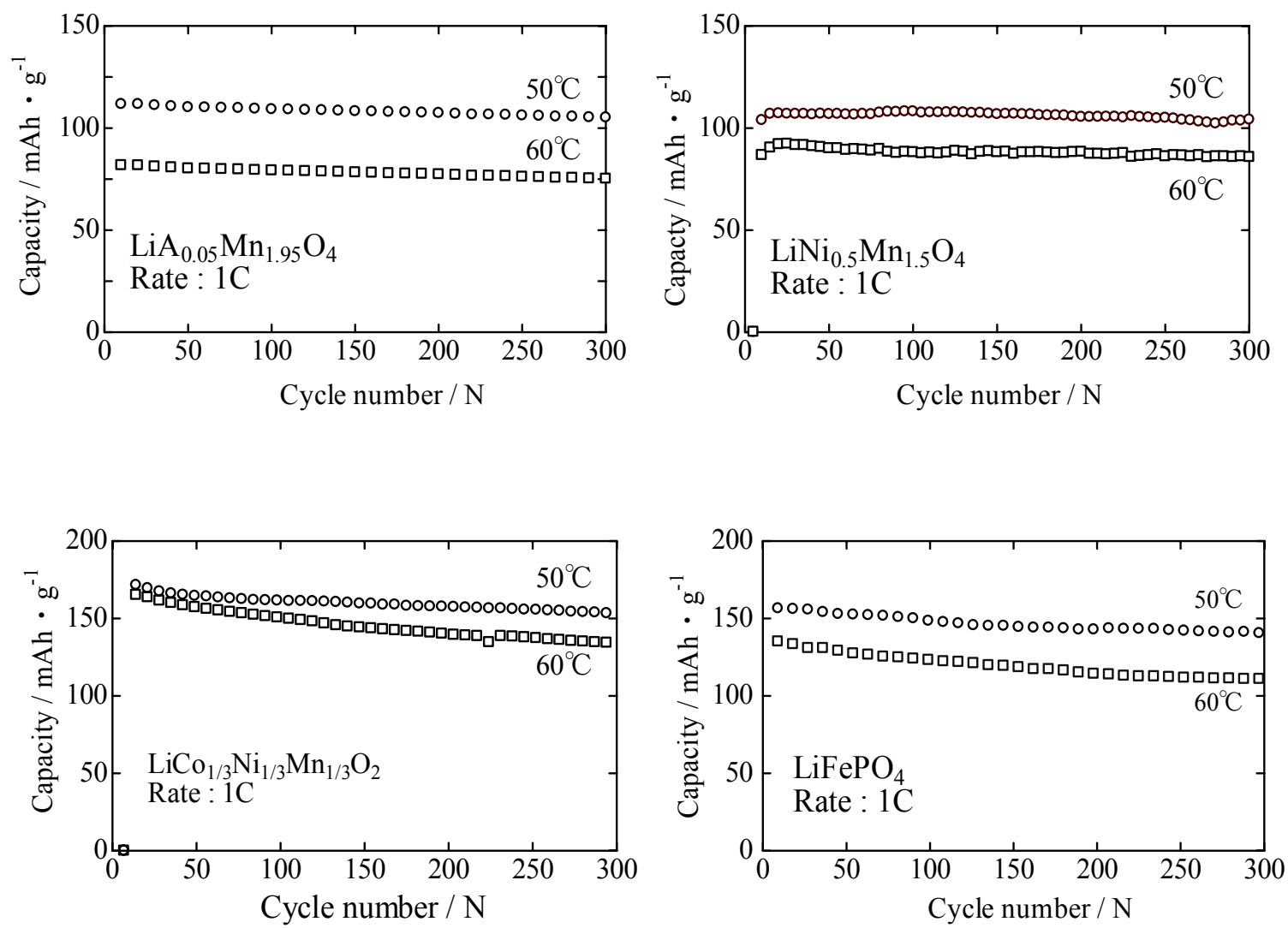

Fig.7 Relation between capacity and cycle number at temperature indicated. 
Figure 8
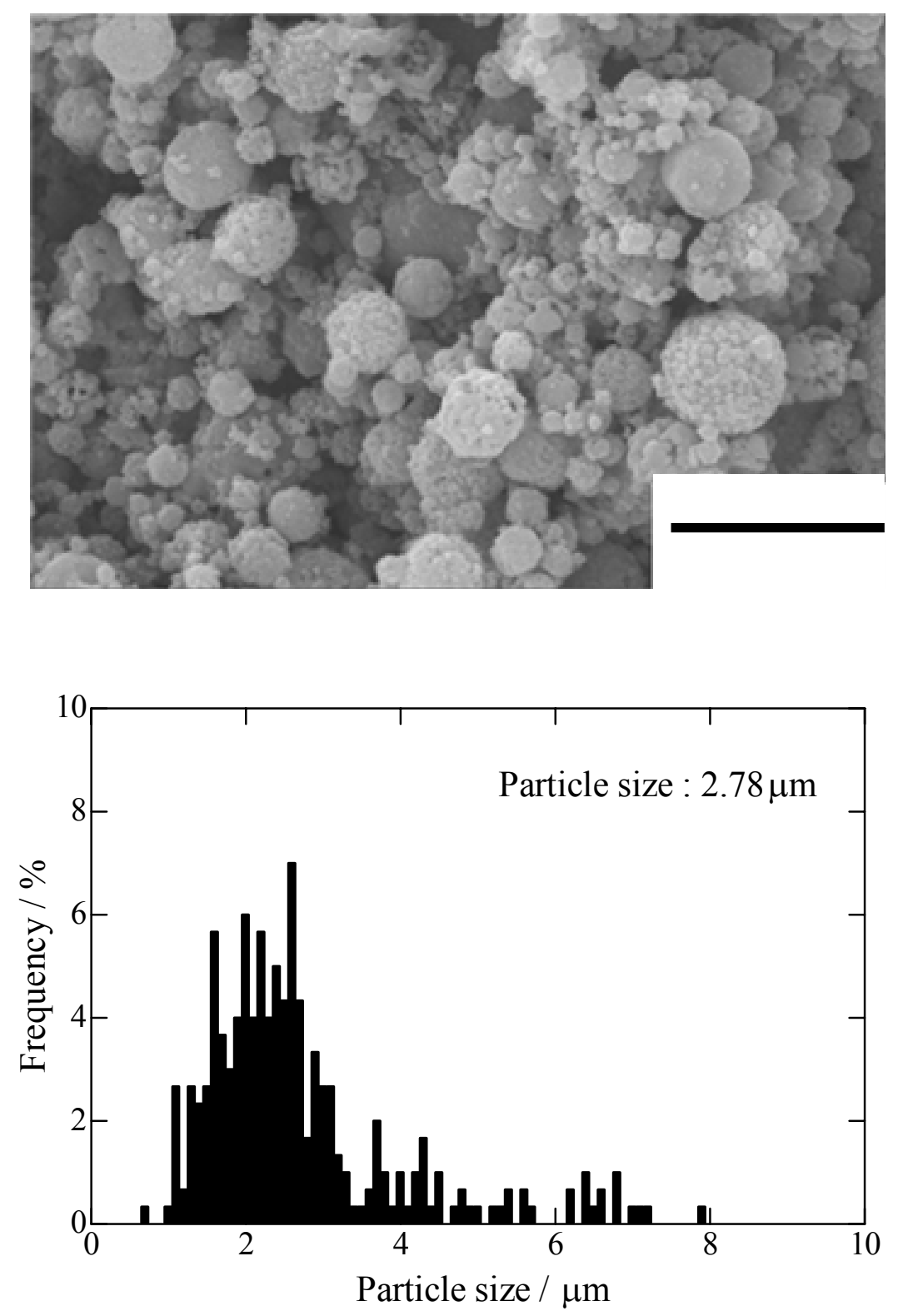

Fig.8 SEM photograph and particle size distribution of $\mathrm{LiAl}_{0.05} \mathrm{Mn}_{1.95} \mathrm{O}_{4}$ powders obtained by internal combustion type spray pyrolysis (bar $=10 \mu \mathrm{m})$ 
Figure 9
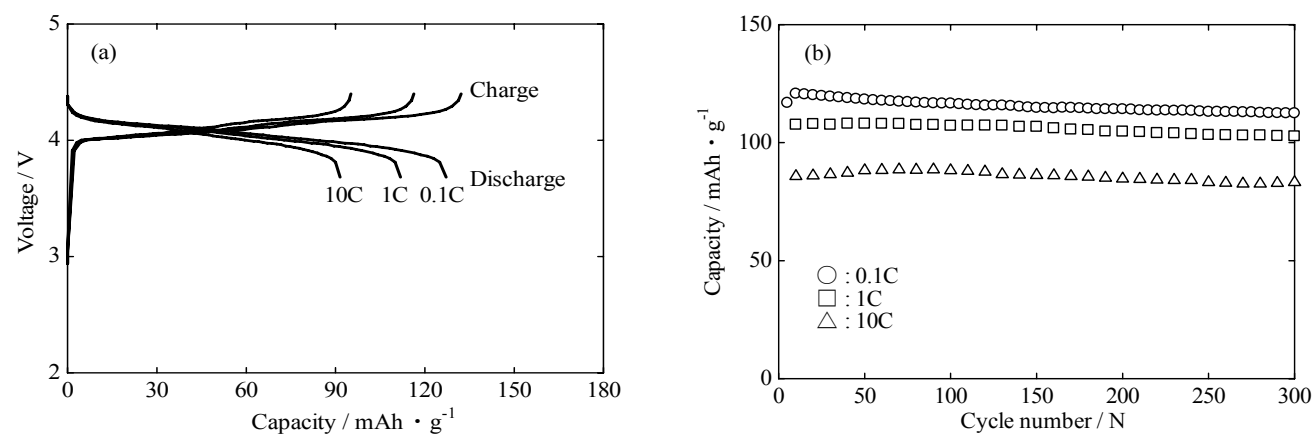

Fig.9 Rechargeable curves (a) and cycle performance (b) of $\mathrm{LiAl}_{0.05} \mathrm{Mn}_{1.95} \mathrm{O}_{4}$ cathode at rate indicated. 